\title{
Suitable Hybrids and Synthetics Provitamin A Maize Selected for Release in the Democratic Republic of Congo
}

\author{
Kabongo Tshiabukole ${ }^{1}$, Pongi Khonde ${ }^{1}$, Mbuya Kankolongo ${ }^{1}$, Tshimbombo Jadika ${ }^{1}$, \\ Kaboko Kasongo ${ }^{1}$, Mulumba Badibanga ${ }^{1}$, Tshibanda Kasongo ${ }^{1}$, Kizungu Vumilia ${ }^{2}$ \\ ${ }^{1}$ Institut National Pour l'Etude et la Recherche Agronomiques (INERA), Kinshasa, Gombe \\ ${ }^{2}$ Biométrie et Expérimentation, INERA DG \& Université de Kinshasa, Kinshasa, Gombe \\ Email: `jpkabon2005@gmail.com
}

How to cite this paper: Tshiabukole, K., Khonde, P., Kankolongo, M., Jadika, T., Kasongo, K., Badibanga, M., Kasongo, T. and Vumilia, K. (2017) Suitable Hybrids and Synthetics Provitamin A Maize Selected for Release in the Democratic Republic of Congo. Open Access Library Journal, 4: e3446.

https://doi.org/10.4236/oalib.1103446

Received: February 7, 2017

Accepted: October 28, 2017

Published: October 31, 2017

Copyright $\odot 2017$ by authors and Open Access Library Inc.

This work is licensed under the Creative Commons Attribution International License (CC BY 4.0).

http://creativecommons.org/licenses/by/4.0/

(c) (i) Open Access

\begin{abstract}
Six new provitamin A hybrids (LY1001-14, LY1001-22 and LY1001-23,) and synthetic maize varieties (PVASYN13, PVASYN9 and PVASYN7) were tested for their agronomic performance and compared to a locally adapted improved open pollinated variety (SAMARU) in the central and western conditions of DRC. A randomized complete block experiment with four replications was used. Following data were collected: $50 \%$ male and female flowering, plant and ear aspect, diseases incidence, plant height, ear aspect, ear rot and yield. The results showed non-significant differences $(p>0.05)$ in disease incidence and ears rot. Significant differences were observed $(p<0.05)$ for number of days to $50 \%$ of male and female flowering, anthesis-silking interval, plant height, plant aspect, ear aspect, and yield. For yield, two hybrids (LY100-14 and LY1001-22) respectively out-yielded local check by $71 \%$ and $56 \%$ while one synthetic (PVASYN 9) out-yielded the local check by $31 \%$ and the two others were comparable to the local check. Thus the hybrids (LY100-14 and LY1001-22) and synthetic varieties (PVASYN 9 and PVASYN13) are ready to be recommended for release to contribute to better production and nutrition for vulnerable people.
\end{abstract}

\section{Subject Areas}

Agricultural Science

\section{Keywords}

Bio-Fortification, Maize, Agronomic Performance, Provitamin A, INERA DRC 


\section{Introduction}

Maize (Zea mays) is a staple food for more than 1.2 billion people in sub-Saharan Africa and Latin America and is considered a vital crop in the perspective of global nutrition [1] [2]. However, most maize produced and consumed is white and devoid of provitamin A carotenoids [3] [4]. This may partly explain why vitamin A deficiency (VAD) is a major public health problem in sub-Saharan Africa [2] [5] leading to widespread malnutrition [6]. Moreover, poverty makes it virtually impossible for the majority of consumers to obtain vitamin A of animal origin.

The VAD affects between 100 and 140 million children worldwide (FAO/WHO 2002, WHO 2003) and about 33 million pre-school children, pregnant and nursing mothers in Africa, 250,000 to 500,000 children [7] [8] and other diseases [9] [10]. The VAD is responsible for approximately $20 \%-24 \%$ of infant mortality due to diarrhea and malaria and infectious diseases [11].

Selection of crops for better nutrition (often called bio-fortification) is one of the strategies to mitigate micronutrient deficiencies [12] [13]. Several initiatives have been launched to increase micronutrient levels in plant foods. The Harvest Plus Challenge Program of the Consultative Group on International Agricultural Research (CGIAR) seeks to combat VAD malnutrition by harnessing the power of plant breeding to develop staple foods such as rice, sweet potatoes, Maize, cassava, wheat and beans rich in iron, zinc or provitamin A [14] [15] [16]. Maize grain (Zea mays L.) has considerable phenotypic diversity for carotenoid profiles [17] [18] [19], including some of the highest concentrations of carotenoids for cereal crops [20].

Bio-fortification of maize varieties with provitamin A by conventional selection is considered as a long-term and sustainable strategy for attenuating VAD in certain target groups [21] [22]. Thus, it becomes necessary to study the agronomic performance of synthetic and hybrid varieties of maize to provitamin A with a goal of spreading superior varieties to vulnerable people.

\section{Materials and Methods}

\subsection{Environment and Experimental Design}

A study was carried out during the rainy season of 2015-2016 in two stations of INERA (Mvuazi and Gandajika) and on-farm at 4 sites (kilonga and kikonka, Muyembi and Musakitshi, respectively around Mvuazi and Gandajika stations). INERA Mvuazi research center, is located at an altitude of $470 \mathrm{~m}$ at $14^{\circ} 54^{\prime}$ East longitude and $5^{\circ} 21^{\prime}$ South latitude. The climate of Mvuazi is of Aw4 type with rainfall ranging from 800 to $1200 \mathrm{~mm}$ per year with monthly averages of the daily air temperature range from $24.5^{\circ} \mathrm{C}$ to $25.5^{\circ} \mathrm{C}$ during the rainy season. Feralsol soil [23] is characterized by low organic matter content and low water retention capacity resulting from low availability of nitrogen [24]. INERA Gandajika research center is located at $06^{\circ} 48^{\prime}$ South latitude, $23^{\circ} 59^{\prime}$ East longitude at altitude between 735 and $766 \mathrm{~m}$. The Gandajika is between is characterized by 
Aw4 climate type with annual rainfalls ranging from $1000 \mathrm{~mm}$ to $1420 \mathrm{~mm}$ and temperature ranging between $22^{\circ} \mathrm{C}$ and $25^{\circ} \mathrm{C}$ (Bado, 1993).

Three hybrids (LY1001-14, LY1001-22, LY1001-23) and three synthetics (PVA SYN 7, PVA SYN 9, PVA SYN 13) all rich in provitamin A from International Institute of Tropical Agriculture (IITA), were tested and compared with an improved control (SAMARU) already adapted in DRC maize producing areas. A randomized complete block experiment with four replications was used.

The soil was plowed and harrowed in late August 2015. Planting was done at a density of 53,333 plants per hectare at the spacing of $0.75 \mathrm{~m} \times 0.50 \mathrm{~m}$. Urea $46 \%$ and NPK 17-17-17 were used as fertilizers. NPK was applied at $250 \mathrm{~kg} / \mathrm{ha}$ at planting time while urea $(120 \mathrm{~kg} / \mathrm{ha})$ was applied in two halves, 15 and 30 days after sowing. Manuel weeding was used to maintain the field experiment clean.

During the growth phase, the data were collected on the vegetative parameters proposed by [25] the number of days at 50\% of male flowering (POLLEN), 50\% to female flowering (DYSK), the height of the plant (PLHT), plant aspect (PASP), and disease Symptom (D.S), ear height (EHT), interval between female and male flowering (IFM). At harvest, maize cobs were harvested on the two central rows of each plot. Data were collected on the ear rot (EROT), ear aspect (EASP) and yield (YIELD) evaluated at $14 \%$ grain moisture. To assess PASP and EASP, a rating scale of 1 to 5 was used $(1=$ excellent, $2=$ very good, $3=$ good, 4 = poor and $5=$ very poor $)$. For EROT and D.S we used: $(1=$ no symptoms, $2=$ very few symptoms, $3=$ moderate infection, $4=$ severe infection and $5=$ very severe infection) [26].

\subsection{Statistical Analysis}

All data collected were subjected to analysis of Variance (ANOVA) using the general linear model AnovaModel <- aov ( $\mathrm{y} \sim$ variety + rep) of Ri3.1.3 to compute the means and to estimate the variety and site effects. The degree of variation was determined using the percentage of the coefficient of variation and the mean characters were measured using the smallest significant difference (LSD) at $P<0.05$. Principal component analysis (PCA) was developed to show the levels of dependence between factors and variables studied.

\section{Results and Discussion}

Data related to plant development and yield components are summarized in Table 2. Based on data generated by the analysis of variance (Table 1) for all sites, the environment significantly and differently affected all parameters considered. Grain yield was determined by the pedigree while the interactions site ${ }^{*}$ pedigree significantly influenced flowering period, plant and ear aspects.

\subsection{Number of Days at $50 \%$ Bloom and Flowering Interval}

The results presented in Table 2 show that there is a significant difference ( $p<$ 0.05) among the pedigrees for the male flowering (POLLEN). 
Table 1. Analysis of variance for growth and yield variables (site and pedigree).

\begin{tabular}{cccccccccccc}
\hline $\begin{array}{c}\text { Source of } \\
\text { variation }\end{array}$ & DF & DYSK & POLLEN & PLHT & EHT & PASP & EASP & EROT & YIELD & D.S \\
\hline Site & 1 & $<2.2 \mathrm{e}-16^{* * *}$ & $2.7 \mathrm{e}-10^{* * *}$ & $<2.2 \mathrm{e}-16^{* * *}$ & $<2 \mathrm{e}-16^{* * *}$ & $8.7 \mathrm{e}-09^{* * *}$ & $0.01^{*}$ & $7.40 \mathrm{e}-06^{* * *}$ & 0.2 & $0.0016^{* *}$ \\
Pedigree & 6 & $1.26 \mathrm{e}-05^{* * *}$ & $0.0001^{* * *}$ & $0.01^{* *}$ & 0.05. & $6.7 \mathrm{e}-09^{* * *}$ & $7.16 \mathrm{e}-05^{* * *}$ & 0.63 & $0.01^{*}$ & 0.83 \\
Site*Pedigree & 6 & $1.24 \mathrm{e}-05^{* * *}$ & $6.4 \mathrm{e}-06^{* * *}$ & 0.27 & 0.55 & $1.07 \mathrm{e}-05^{* * *}$ & $0.026^{*}$ & 0.54 & 0.66 & 0.569 \\
\hline
\end{tabular}

Signif. codes: 0 “***» 0.001 “**» 0.01 “*” 0.05 “.” 0.1 “” 1 .

Table 2. Regional averages of six sites for synthetics and hybrids varieties based on growth and yield data.

\begin{tabular}{cccccccccccc}
\hline PEDIGREE & DYSK & POLLEN & IFM & PLHT $(\mathrm{cm})$ & EHT $(\mathrm{cm})$ & $\begin{array}{c}\text { PASP } \\
(1-5)\end{array}$ & $\begin{array}{c}\text { EASP } \\
(1-5)\end{array}$ & $\begin{array}{c}\text { EROT } \\
(1-5)\end{array}$ & $\begin{array}{c}\text { YIELD } \\
(\mathrm{kg} / \mathrm{ha})\end{array}$ & $\begin{array}{c}\text { D.S } \\
(1-5)\end{array}$ \\
\hline LY1001-22 & $63.5 \mathrm{bc}$ & $58.7 \mathrm{bc}$ & $4.75 \mathrm{ab}$ & $187.8 \mathrm{a}$ & $92.49 \mathrm{abc}$ & $2.00 \mathrm{~d}$ & $2.31 \mathrm{abc}$ & $1.56 \mathrm{a}$ & $6.47 \mathrm{a}$ & $1.75 \mathrm{a}$ \\
LY1001-14 & $64.5 \mathrm{~b}$ & $59.75 \mathrm{~b}$ & $4.75 \mathrm{ab}$ & $186.15 \mathrm{a}$ & $85.34 \mathrm{bcd}$ & $2.18 \mathrm{~cd}$ & $1.8 \mathrm{~d}$ & $1.43 \mathrm{a}$ & $5.90 \mathrm{ab}$ & $1.62 \mathrm{a}$ \\
LY1001-23 & $67.5 \mathrm{a}$ & $61.8 \mathrm{a}$ & $5.37 \mathrm{a}$ & $184.34 \mathrm{ab}$ & $94.62 \mathrm{a}$ & $2.43 \mathrm{bc}$ & $2.06 \mathrm{~cd}$ & $1.93 \mathrm{a}$ & $4.46 \mathrm{~cd}$ & $1.75 \mathrm{a}$ & \\
PVASYN13 & $64.12 \mathrm{~b}$ & $59.7 \mathrm{~b}$ & $4.37 \mathrm{ab}$ & $182.71 \mathrm{ab}$ & $91.59 \mathrm{abc}$ & $2.43 \mathrm{bc}$ & $2.56 \mathrm{ab}$ & $1.75 \mathrm{a}$ & $4.40 \mathrm{~cd}$ & $1.5 \mathrm{a}$ \\
PVASYN9 & $62.8 \mathrm{bc}$ & $59 \mathrm{~b}$ & $3.87 \mathrm{~b}$ & $188.49 \mathrm{a}$ & $95.48 \mathrm{a}$ & $2.18 \mathrm{~cd}$ & $2.68 \mathrm{a}$ & $1.75 \mathrm{a}$ & $4.97 \mathrm{bc}$ & $1.62 \mathrm{a}$ \\
PVASYN7 F2 & $64.37 \mathrm{~b}$ & $60.12 \mathrm{~b}$ & $4.25 \mathrm{ab}$ & $170.17 \mathrm{ab}$ & $83.84 \mathrm{~cd}$ & $2.87 \mathrm{a}$ & $2.62 \mathrm{ab}$ & $1.62 \mathrm{a}$ & $3.54 \mathrm{~d}$ & $1.5 \mathrm{a}$ \\
SAMARU & $61.8 \mathrm{c}$ & $57.3 \mathrm{c}$ & $4.5 \mathrm{a}$ & $162.65 \mathrm{~b}$ & $80.31 \mathrm{~d}$ & $2.56 \mathrm{~b}$ & $2.87 \mathrm{a}$ & $1.75 \mathrm{a}$ & $3.79 \mathrm{~cd}$ & $1.87 \mathrm{a}$ \\
Means & 64.07 & 59.51 & 4.55 & 180.33 & 98.1 & 2.38 & 2.42 & 1.68 & 4.79 & 1.64 \\
CV\% & 2.56 & 2.25 & 23.48 & 7.8 & 11.11 & 8.2 & 15.18 & 31.12 & 26.27 & 32.87 \\
LSD (0.05\%) & 2.17 & 1.27 & 1.33 & 16.36 & 14.88 & 0.29 & 0.39 & 0.52 & 2.71 & 0.43 \\
\hline
\end{tabular}

$(a, b, c)$ : Averages with the same letters are not significantly different at $5 \%$ of error.

Local (SAMARU) check flowered early at 57.3 days while LY1001-23 followed at 61.8 days. For female flowering, the significant difference was observed with SMARU with 61.8 days and LY1001-23 at 67.5 days. Similarly to the number of days $50 \%$ to flowering, there was a significant difference $(p<0.05)$ for the flowering interval (IFM) among the treatments. PVASYN9 exhibited a shorter IFM of 3.8 days while LY1001-22 and LY1001-14 presented a longer IFM of 4.75 days. [27] [28] working on high amino acid varieties showed that the flowering interval was significantly correlated with yield. Short IFM varieties $($ IFM $<4)$ had higher yields than long IFM (IFM $>3$ ). Contrasting varieties rich in amino acids, hybrid varieties rich in provitamin A are fairly important beyond IFMs $>3$ days. This implies that pollen production for these varieties would extend over a long period to the end of female flowering.

\subsection{Plant Height}

Results obtained from this study indicate that there was a significant difference $(p<0.05)$ among maize varieties for plant height. SAMARU showed a shorter size of $162.65 \mathrm{~cm}$ while the highest genotype was the PVASYN9 with $188.49 \mathrm{~cm}$ (Table 1). Plant and ear heights are perceived as signs of vigor, so short, low-insertion plants are needed in the tropical breeding program to improve 
stem and root resistance and facilitate harvesting [29]. [30] found that the height of the plant was significantly correlated with grain yield while [31] showed that plant height reduction improved yield by giving the variety the ability to respond to high density without lodging by maintaining or reducing barrier levels.

\subsection{Plant and Ear Aspect}

Plant aspect is a visual measurement of how good and appealing the plants are morphologically. The results obtained in this study show that the plant aspect was not significantly affected for most varieties. For the ear aspect, the criterion included cobs uniformity and size, kernel arrangement, and ear rot tolerance. PVASYN7 was more affected with a worse plant aspect around 3. The other varieties presented a very good appearance for plants and ears.

\subsection{Disease Incidence and Ear Rot Indexes}

For all maize varieties evaluated, PVASYN13, PVASYN7, LY100-22 and LY1001-23 had low infection rates than 1.7. SAMARU showed infection rates around 1.9. However, no significant differences were observed among the varieties tested. As for the disease incidence, there were no significant differences among the varieties for ear rot indexes. All the seven varieties had a rotational ear rot index ranging from 1 to 1.7 .

\subsection{Grain Yield (t/ha) and Planting Sterile Rate (\%)}

The yield obtained was significantly influenced by the potential of the different maize varieties tested. Two hybrids LY1001-14 (5.9 t/ha) and LY1001-22 (6.5 $\mathrm{t} / \mathrm{ha}$ ) obtained significantly higher yields than the hybrid LY1001-23 (4.5 t/ha) and all synthetics except PVASYN9 which got a yield similar to that of one of the hybrids (LY1001-14), which makes it a best potential candidate for release. Grain yield is a complex trait. It is the product of several components including the number of ears per plant, the number of grains per ear and the grain weight. According to [32] [33] its heritability is low (0.09 to 0.38 ). The low correlations between the rate of sterile plants and the yield indicate that yield is not always influenced at low values $<10 \%$ of sterile plants. Genotypes LY1001-14, LY1001-22 and PVASYN13 have been reported as provitamin-A rich materials with high production, disease resistance and good returns in Ghana [6].

\subsection{Principal Component Analysis (PCA)}

Only four of the ten dimensions obtained Eigen values greater than 1 . These dimensions provide $76.08 \%$ of the total variance (Figure 1). The first two axes PC1 and PC2 account for $64 \%$ of information. The PC1 axis better explains plant height (PLHT) and ear height (EHT) and female flowering (DYSK) and male flowering (POLLEN). The axis PC2 explains better YIELD and ear aspect (EASP).

The PC1 is defined by male flowering (POLLEN), female flowering (DYSK), 


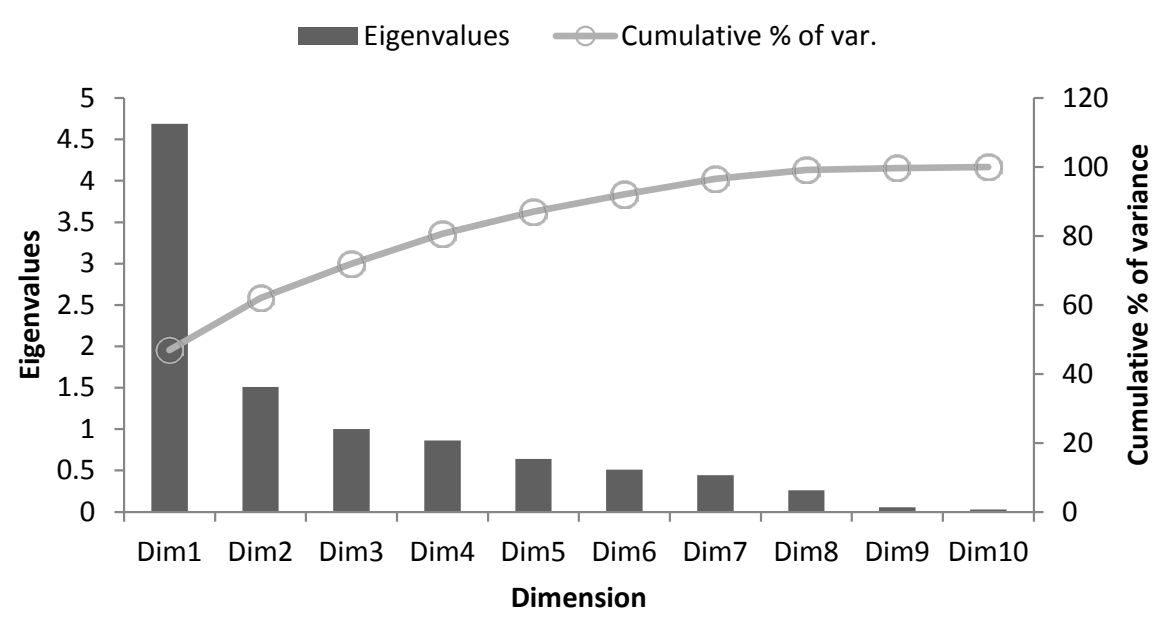

Figure 1. Eigenvalues of factors and cumulative $\%$ of factor variance.

PLHT et EHT and the ear aspect (EASP), plant aspect and flowering interval (IFM).

This dimension contrasts early maturing varieties with a high yield to late maturing varieties at long IFM. The PC2, mainly defined by the flowering interval (IFM), female flowering and plant aspect, two contrasts groups, 1) the more synchronized varieties in flowering with a noticeable plant and ears aspect, and 2) the varieties having a longer flowering interval, undesirable ear aspect and low yield (Figure 2). PC3 characterizes varieties plant height. The PC4, characterized by yield and the sterile plants rate, contrasts high yielding genotypes with fewer sterile plants with less productive genotypes with a high sterile plant rate. The first dimension categorizes synthetic varieties (PVASYN9 and PVASYN13) having medium plant height, good aspect and high yield (Figure 3). The second dimension characterizes the hybrids varieties

(LY1001-22, LY1001-14 and LY1001-23) having a good plant and ear aspect and a longer or shorter IFM. However, the PVASYN7 variety was opposed to the two groups of varieties. It has a high plant aspect index and low grain yield. The local check (SAMARU) showed to be an intermediate variety from the two types of varieties. It is short sized, with good plant and very good ear aspects.

Figure 3 shows a clear separation between varieties types. This separation of hybrids and synthetics varieties has been reported by [6] [29]. PVAs have a low yield compared to LYxxx.

Table 3 presents four groups from the PCA for the parameters studied. These are groups formed of PVA syn 9 and PVA syn 13, PVA syn7 and Local check, LY1001-14 and LY1001-22, and LY1001-23.

In the first case, the PVASYN13 and PVASYN9 varieties were more effective in disease resistance and good yield in an assessment in Nigeria. In the second case, the hybrids (LY1001-14 and LY1001-22) were tested in Ghana for their yield performance, provitamin A content, and plant and ear aspects. In both cases the results remained similar to those obtained in our study.

Based on of the results obtained during this evaluation, the two types of 


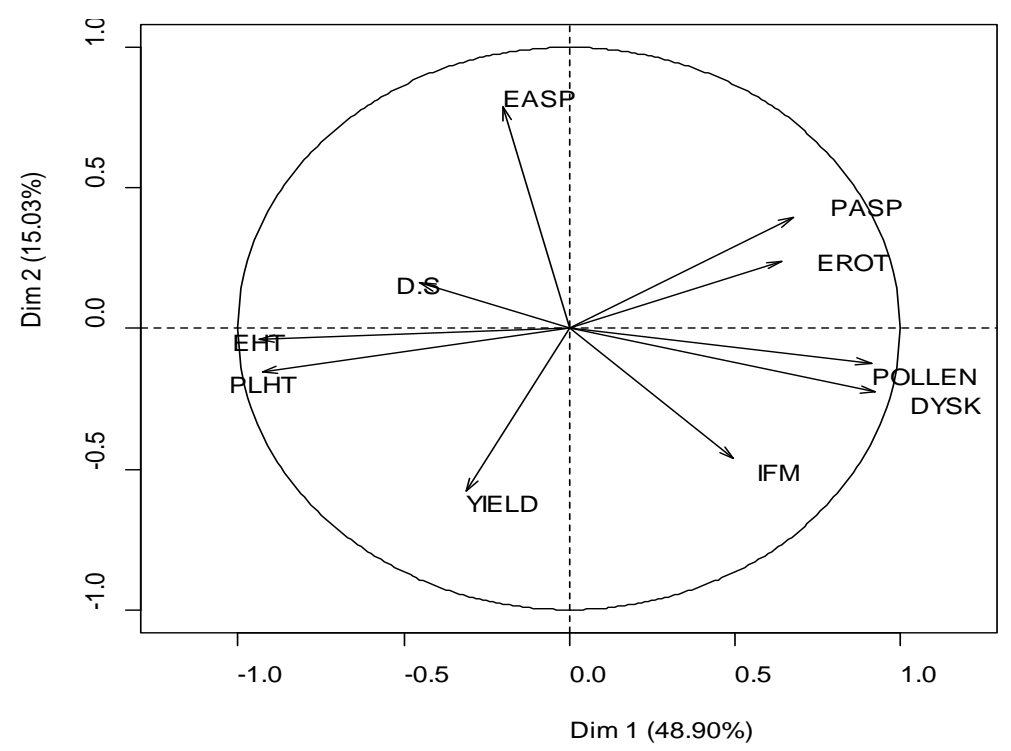

Figure 2. Vector projection from the ACP.

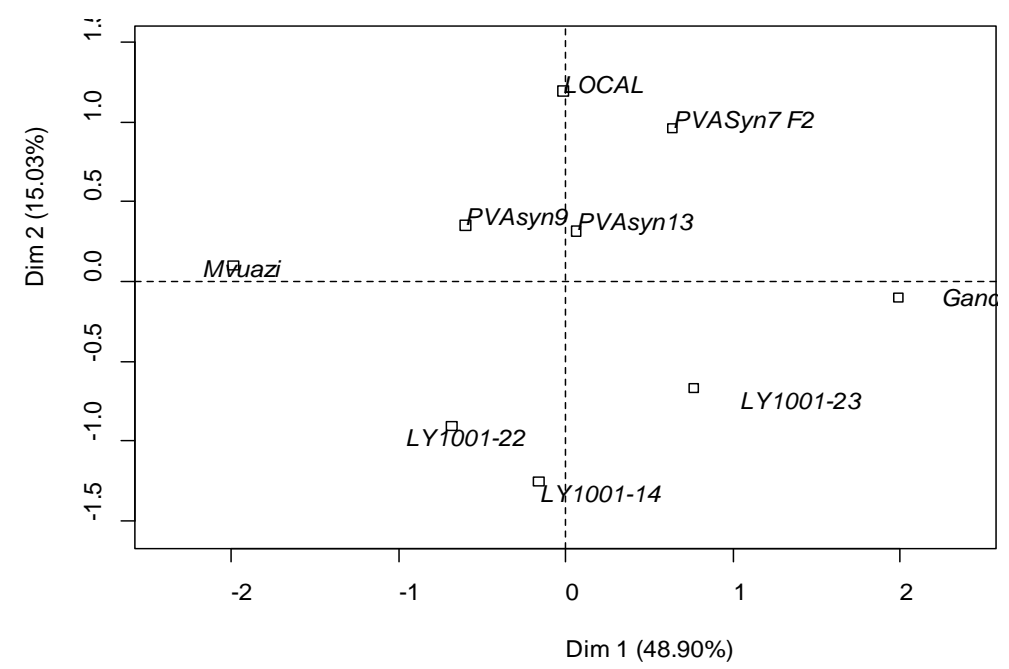

Figure 3. Biplot showing the separation of genotypes according to the studied parameters.

Table 3. Morphological, phenological and varieties characteristics studied in all sites.

\begin{tabular}{ccccc}
\hline \multirow{2}{*}{ Variables } & I & II & III & IV \\
\cline { 2 - 5 } & PVA Syn 9 & LY1001-22 & LY1001-23 & PVA Syn7 \\
\hline EASP & Hight & Low & Low & Hight \\
EHT PLHT & Hight & Hight & Low & Low \\
YIELD & Low & Hight & Hight & Low \\
PASP & Low & Low & Hight & Hight \\
EROT & Low & Low & Low & Low \\
POLLEN DYSK & Low & Low & Hight & Hight \\
IFM & Low & Hight & Hight & Low \\
DS & Hight & Low & Low & Light \\
\hline
\end{tabular}


genotypes performed differently in comparison with the improved non-biofortified control. Synthetic varieties with earlier synchronized flowering have been characterized by their low sterility compared to intermediate maturing hybrids. The ear aspect, sterility rate, plant height and flowering interval indicated of genotype productivity potential.

\section{Conclusion}

Three new provitamin A hybrids (LY1001-14, LY1001-22 and LY1001-23) and three synthetic maize varieties (PVASYN13, PVASYN9 and PVASYN7) were tested for their agronomic performance. Out of them, two hybrids (LY100-14 and LY1001-22) and two synthetics (PVASYN9 and PVASYN13) performed well with high yield potential. Thus they are good candidates to be recommended for release for the first time to contribute to better production and nutrition for vulnerable people in DRC.

\section{Acknowledgements}

The Harvest Plus program of the International Institute of Tropical Agriculture (IITA/Ibadan Nigeria) is highly acknowledged for funding this project. The authors are also grateful to Dr. Menkir Abebe and Dr. Silvestro Meseka of IITA maize breeding Program and their staff who worked hard to provide material for the project implementation in DRC.

\section{References}

[1] International Institute of Tropical Agriculture (IITA) (2010) New Varieties to Boost Maize Output in West and Central Africa.

http://www.iita.org/news-item/new-varieties-boost-maize-output-west-central-afric a/, Accessed 2 November 2010.

[2] Nuss, E.T. and Tanumihardjo, S.A. (2010) Maize: A Paramount Staple Crop in the Context of Global Nutrition. Comprehensive Reviews in Food Science and Food Safety, 9, 417-436. https://doi.org/10.1111/j.1541-4337.2010.00117.x

[3] Menkir, A., Liu, W., White, W.S., Maziya-Dixon, B. and Rocheford, T. (2008) Carotenoid Diversity in Tropical-Adapted Yellow Maize Inbred Lines. Food Chemistry, 109, 521-529.

[4] Li, S., Tayie, F.A.K., Young, M.F., Rocheford, T. and White, W.S. (2007) Retention of Provitamin A Carotenoids in High $\beta$-Carotene Maize (Zea Mays) during Traditional African Household Processing. Journal of Agricultural and Food Chemistry, 55, 10744-10750. https://doi.org/10.1021/jf071815v

[5] Micronutrient Initiative (2004) Vitamin \& Mineral Deficiency, A Global Progress Report. http://www.micronutrient.org/S, Accessed 4 January 2006.

[6] Ewool, M.B., Akromah, R. and Acheampong, P.P. (2016) Performance of Pro-Vitamin A Maize Synthetics and Hybrids Selected for Release in Ghana. International Journal of Science and Technology, 5, 268-291.

[7] West, K.P. (2002) Extent of Vitamin A Deficiency among Preschool Children and Women of Reproductive Age. Journal of Nutrition, 132, 2857-2866.

[8] Lila Laborde et Jean Pierre Toutant. [Maize Rich in Provitamin A.] 2008. 
https://www.france-science.org/Du-mais-riche-en-vitamine-A.html

[9] FAO/WHO (2002) Human Vitamin and Mineral Requirements. Report of a Joint FAO/WHO Expert Consultation Bangkok, Thailand. Rome, Italy.

http://www.fao.org/3/a-y2809e.pdf

[10] WHO (OMS) (2003) Combating Vitamin A Deficiency. WHO Website, Updated September 2003. World Health Organisation, Rome, Italy. http://www.who.int/nutrition/topics/vad/en/

[11] Rice, A.I., West, K.P. and Black, R.E. (2004) Vitamin A Deficiency. In: Comparative Quantification of Health Risks. http://www.who.int/publications/cra/chapters/volume1/0211-0256.pdf

[12] Welch, R.M. and Graham, R.D. (2002) Breeding Crops for Enhanced Micronutrient Content. Plant and Soil, 245, 205-214. https://doi.org/10.1023/A:1020668100330

[13] Bouis, H.E., Chassy, B.M. and Ochanda, J.O. (2003) Genetically Modified Food Crops and Their Contribution to Human Nutrition and Food Quality. Trends in Food Science \& Technology, 14, 191-209.

[14] Harvest Plus (2004) Breeding Crops for Better Nutrition. http://www.harvestplus.org/sites/default/files/brochure.pdf

[15] Tanumihardjo, S.A. (2008) Food-Based Approaches for Ensuring Adequate Vitamin A Nutrition. Comprehensive Reviews in Food Science and Food Safety, 7, 373-381.

[16] HarvestPlus Brief (2006) HarvestPlus: Breeding Crops for Better Nutrition. Washington DC.

[17] Harjes, C.E., Rocheford, T.R., Bai, L., Brutnell, T.P., Kandianis, C.B., Sowinski, S.G., Stapleton, A.E., Vallabhaneni, R., Williams, M., Wurtzel, E.T., Yan, J. and Buckler, E.S. (2008) Natural Genetic Variation in Lycopene Epsilon-Cyclase Tapped for Maize Biofortification. Science, 319, 330-333. https://doi.org/10.1126/science

[18] Berardo, N., Mazzinelli, G., Valoti, P., Lagana, P. and Redaelli, R. (2009) Characterization of Maize Germplasm for the Chemical Composition of the Grain. Journal of Agricultural and Food Chemistry, 57, 2378-2384. https://doi.org/10.1021/jf803688t

[19] Burt, A., Grainger, C., Young, C., Shelp, B. and Lee, E. (2010) Impact of Postharvest Handling on Carotenoid Concentration and Composition in High-Carotenoid Maize (Zea mays L.) Kernels. Journal of Agricultural and Food Chemistry, 58, 8286-8292. https://doi.org/10.1021/jf100161r

[20] Abdel-Aal, E.M., Young, J.C. and Rabalski, I. (2006) Anthocyanin Composition in Black, Blue, Pink, Purple, and Red Cereal Grains. Journal of Agricultural and Food Chemistry, 54, 4696-4704. https://doi.org/10.1021/jf0606609

[21] Howe, J.A. and Tanumihardjo, S.A. (2006) Carotenoid-Biofortified Maize Maintains Adequate Vitamin a Status in Mongolian Gerbils. Journal of Nutrition, 136, 2562-2567.

[22] Nestel, P., Bouis, H.E., Meenakshi, J.V. and Pfeiffer, W. (2006) Biofortification of Staple Food Crops. Journal of Nutrition, 136, 1064-1067.

[23] FAO (2007) Système d'information des ressources en alimentation animale. [Animal Feed Resource Information System.] $52 \mathrm{p}$.

[24] Fakorede, M.A.B., Badu-Apraku, N., Coulibaly, O. and Fajemisin, J.M. (2001) Maize Research and Development Priorities in Sub-Saharan African in the Next Millennium. 31-58.

[25] Vasal, S.K., Cordova, H., Beck, D.L. and Edmeades, G.O. (1997) Choices among Breeding Procedures and Strategies for Developing Stress Tolerant Maize 
Germplasm. In: Edmeades, G.O., Bänziger, M., Michelson, H.R. and Pena-Valdiva, C.B., Eds., Developing Drought and Low N-Tolerant Maize, Proceedings of a Symposium, Mexico, 25-29 March 1996, 336-347.

[26] Bello, O.B., Ganiyu, O.T., Wahab, M.K.A., Azeez, M.A., Abdulmaliq, S.Y., Ige, S.A., Mahmood, J., Oluleye, F. and Afolabi, M.S. (2012) Yield and Disease Reactions of Quality Protein Maize Varieties in the Southern Guinea Savanna Agro-Ecology of Nigeria. International Journal of Agriculture and Forestry, 2, 203-209.

[27] Kabongo, T., Pongi, K., Mumba, J., Mbuya, K., Kizungu, V. and Kabwe, K. (2016) Evaluation of Maize Sensitivity to Drought in Southwestern Savannah Area of DR. Congo. African Journal of Agricultural Science and Technology, 4, 812-817.

[28] Hema, D., Kim, S.K., Mondeil, F., Tio-Toure, B.B. and Tapsoba, A. (2001) Intervalle Entre Floraison mâle et femelle chez le maïs: Son importance en sélection pour la tolérance à la sécheresse. [Interval between Male and Female Flowering in Corn: Its Importance in Selection for the tolerance to Drought.] Cahiers Agricultures Août, 10, 255-260.

[29] Feyisola, R.T., Godonu, K.G., Oduwaiye, T.R. and Lamidi, G.O. (2016) Disease Tolerance and Yield Attributes of Yellow Open Pollinated Maize Varieties in South Western Nigeria. Natural Science, 14, 23-28.

[30] El-Lakany, M.A. and Russel, W.A. (1971) Relationship of Maize Characters with Yield in Testcrosses of Inbreds at Different Plant Densities. Crop Science, 11, 698-701. https://doi.org/10.2135/cropsci1971.0011183X001100050028x

[31] Bjarnason, M., Edmeades, G.O. and Ortega, A. (1971) Improvement of Some Important Traits of Tropical Maize. In: Brandolini, A. and Salamini, F., Eds., Breeding Strategies for Maize Production Improvement in the Tropics, FAO/Instituto Agronomico per l'Oltremare, Firenze, 409-428.

[32] Ordas, A., Malvar, R.A. and de Ron, A.M. (1987) Heritability of Several Traits in an Early Population of Maize. No. 88-100208.CIMMYT.

[33] Claudio-Jobet, F. and Patricio Barriga, B. (1988) Genetic Variance of Yield and Other Quantitative Characters in a Population of Maize. I Estimation of the Components of Variance and Heritability. Agronomy Surmary, 16, 73-83.

Submit or recommend next manuscript to OALib Journal and we will provide best service for you:

- Publication frequency: Monthly

- 9 subject areas of science, technology and medicine

- Fair and rigorous peer-review system

- Fast publication process

- Article promotion in various social networking sites (LinkedIn, Facebook, Twitter, etc.)

- Maximum dissemination of your research work

Submit Your Paper Online: Click Here to Submit

Or Contact service@oalib.com 